\title{
Application of chalcones in heterocycles synthesis: Synthesis of 2-(isoxazolo, pyrazolo and pyrimido) substituted analogues of 1,4-benzodiazepin-5-carboxamides linked through an oxyphenyl bridge
}

\author{
N KAUR* and D KISHORE \\ Department of Chemistry, Banasthali University, Banasthali 304 022, India \\ e-mail: nvjithaans@gmail.com
}

MS received 9 September 2012; revised 1 December 2012; accepted 21 January 2013

\begin{abstract}
Versatility of chalcone derivative of 2-(4'-acetyl)-phenoxyl-5-carboxamido-1,4-benzodiazepin-5(4'-methylpiperazinyl)-carboxamide (6) was explored to provide an easy one-pot access to its 2-(isoxazolo, pyrazolo and pyrimido) substituted analogues $9,10,11,12,13,14,15$, and 16.
\end{abstract}

Keywords. 1,4-Benzodiazepine; chalcone; isoxazole; pyrazole; pyrimidine.

\section{Introduction}

Eversince, 1,4-benzodiazepines have been recognized as 'privileged medicinal scaffolds' ${ }^{1}$ by virtue of their ability to provide ligands to a number of functionally and structurally discrete biological receptors, ${ }^{2}$ the interest on the various facets of the chemistry of these materials has expanded exponentially, thereafter. On account of their impressive biological properties such as psychopharmacological, anticancer, anti HIV, etc. (to name a few) this nucleus has remained in the mainstay as evergreen medicinal scaffold from which potential drug candidates can be expected. ${ }^{3-5}$

The advent of anti HIV (human immunodeficiency virus) activity in 1,4-benzodiazepine derivative [TIBO ${ }^{6}$ (a) $(4,5,6,7$-tetrahydro-5-methylimidazo[4,5,1-jk $][1,4]$ benzodiazepin-2(1H)-one)], the dipyrido diazepine derivative (nevirapine) ${ }^{7}$ (b), pyrimidine derivative (etravirine $)^{8}(\mathbf{c})$, (figure 1) and in isoxazole and pyrazole derivatives, ${ }^{9}$ prompted us to explore the possibility of developing some such analogues of 1,4benzodiazepines which contained in its nucleus the vital fragments of etravirine together with isoxazole, pyrazole, and pyrimidine scaffolds ${ }^{10}$ on the premise that their presence in tandem with the same molecular framework could contribute significantly to provide a beneficial effect on the overall biological efficacy in the resulting molecules.

The presence of $\alpha-\beta$ unsaturated keto function makes chalcone very prone to undergo reactions with

*For correspondence

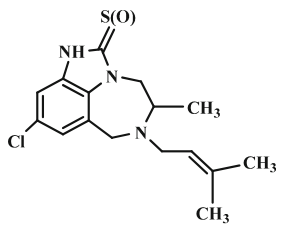

(a)

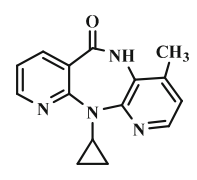

(b)

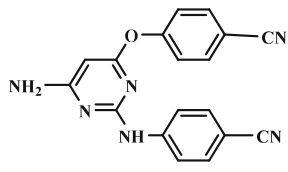

(c)
Figure 1. Structures of TIBO (a), Nevirapine (b), Etravirine (c).

bidentate nucleophiles to give five, six and sevenmembered heterocyclic compounds. This property of chalcone was exploited in the present work to generate isoxazoles, pyrazolo and pyrimido incorporated derivatives of biological interest. We intended to utilize this procedure to explore the formation of 9-16 containing the isoxazole, pyrazole, and pyrimidine rings linked on 2-position of 1,4-benzodiazepine nucleus through an oxyphenyl spacer.

\section{Experimental}

All melting points were determined in open glass capillaries and are uncorrected. The IR spectra were recorded on $\mathrm{KBr}$ disc using Perkin Elmer-1800 intrachord. ${ }^{1} \mathrm{H}$ NMR and ${ }^{13} \mathrm{C}$ NMR spectra were recorded in $\mathrm{CDCl}_{3}$ on Brucker Avance $400 \mathrm{MHz}$ spectrophotometer with TMS as internal standard (chemical shifts are expressed in $\delta \mathrm{ppm}$ ). The mass spectra were recorded on a Joel SX-102 (EI/CI/FAB) mass spectrometer at $70 \mathrm{eV}$. The reactions were monitored by the TLC on silica 
gel $\mathrm{G}$ plates in the solvent system benzene-methanol mixture (9:1).

$N$-chloroacetylisatin (2) (m.p. $\quad 210-11^{\circ} \mathrm{C}$ ) and methyl-1,3-dihydro-2 $H$-[1,4]-benzodiazepin-2-one-5carboxylate (3) (m.p. $173-75^{\circ} \mathrm{C}$ ) were prepared according to the reported procedure for their preparation in the literature. ${ }^{13,14}$

\subsection{Preparation of 1,3-dihydro-[2H]-[1,4]- benzodiazepin-5-(4'-methylpiperazinyl)- carboxamide (4)}

Methyl-1, 3-dihydro-[2H]-[1, 4]-benzodiazepin-2-one5-carboxylate (3) $(10.9 \mathrm{~g}, 0.05 \mathrm{~mol})$ and $\mathrm{N}$-methyl piperazine $(5.0 \mathrm{~g}, 0.05 \mathrm{~mol})$ were taken in ethanol $(100 \mathrm{~mL})$. The reaction mixture was refluxed for $12 \mathrm{~h}$ on water bath. The completion of the reaction was checked by TLC. The mixture was cooled and poured on ice, the resulting solid was filtered washed with dilute ethanol dried and recrystallized from ethanol-chloroform mixture (1:9), to give 4 (12.37 g, $75 \%$, m.p. $\left.257-258^{\circ} \mathrm{C}\right)$. IR (KBr): 2950, 1660, 1590, 1580, 1510, 1430, 1140; ${ }^{1} \mathrm{H}$ NMR $\left(400 \mathrm{MHz}, \mathrm{CDCl}_{3}\right) \delta 8.0(\mathrm{~s}, 1 \mathrm{H}), 7.27-7.86(\mathrm{~m}$, $4 \mathrm{H}), 3.60$ (s, 2H), 3.20 (t, 4H), 2.27 (t, 4H), 2.23 (s, 3H); MS: $\left[\mathrm{M}^{+}\right]$: 286, Anal. calcd. for $\mathrm{C}_{15} \mathrm{H}_{18} \mathrm{~N}_{4} \mathrm{O}_{2}$ : C, 62.79; $\mathrm{H}, 6.31$; N, 19.54. Found: C, 62.92; H, 6.33; N, 19.48.

\subsection{Preparation of 2-chloro-[1,4]-benzodiazepin-5- (4'-methylpiperazinyl)-carboxamide (5)}

A solution of $4(10 \mathrm{~g}, 0.06 \mathrm{~mol}), \mathrm{POCl}_{3}(5 \mathrm{~mL}$, $0.06 \mathrm{~mol}), \mathrm{N}, \mathrm{N}$-dimethylaniline $(14 \mathrm{~mL}, 0.1 \mathrm{~mol})$, and benzene $(100 \mathrm{~mL})$ were refluxed for $7 \mathrm{~h}$ and allowed to cool overnight. The cold reaction mixture was poured in ice water $(100 \mathrm{~mL})$ and stirred for $30 \mathrm{~min}$ until the reaction mixture reached to room temperature. It was then extracted with ether and the solvent layer was washed with water and brine, dried (over anhydrous $\mathrm{MgSO}_{4}$ ), filtered, and evaporated. Trituration with ether gave 5 ( 8.0 g, $75 \%$, m.p. $\left.120-122^{\circ} \mathrm{C}\right)$. IR (KBr): 2955 , $1670,1590,1570,1505,1435,1140,710 ;{ }^{1} \mathrm{H}$ NMR $\left(400 \mathrm{MHz}, \mathrm{CDCl}_{3}\right) \delta 7.33-7.83(\mathrm{~m}, 4 \mathrm{H}), 3.60(\mathrm{~s}, 2 \mathrm{H})$, $3.20(\mathrm{t}, 4 \mathrm{H}), 2.27$ (t, 4H), 2.26 (s, 3H); MS: $\left[\mathrm{M}^{+}\right]$: 304, Anal. calcd. for $\mathrm{C}_{15} \mathrm{H}_{17} \mathrm{ClN}_{4} \mathrm{O}: \mathrm{C}, 59.24 ; \mathrm{H}, 5.65 ; \mathrm{N}$, 18.34. Found: C, 59.11; H, 5.67; N, 18.28.

\subsection{Preparation of 2-(4'-acetylphenoxyl)-[1,4]- benzodiazepin-5-[4"-methylpiperazinyl)- carboxamide (6)}

To a solution of $\mathbf{5}(8 \mathrm{~g}, \quad 0.024 \mathrm{~mol})$ and $p$ hydroxyacetophenone $(3.80 \mathrm{~g}, 0.025 \mathrm{~mol})$ in DMF $(15 \mathrm{~mL})$ was slowly added potassium-tert-butoxide
$(5.3 \mathrm{~g}, 0.048)$ in an ice-water bath, then stirred at room temperature for $6 \mathrm{~h}$ until reaction was completed. The mixture was poured into ice water and $\mathrm{pH}$ was adjusted to 6 with $5 \%$ aqueous $\mathrm{HCl}$ and the mixture extracted with EtOAc. After removal of organic solvent in vacuo, crude product was purified by TLC or a silica column (eluent: petroleum ether/EtOAc) to give $\mathbf{6}(7.20 \mathrm{~g}, 68 \%$, m.p. $\left.165-167^{\circ} \mathrm{C}\right)$. IR (KBr): 2960, 1680, 1670, 1610, $1580,1510,1430,1155,1030 ;{ }^{1} \mathrm{H}$ NMR $(400 \mathrm{MHz}$, $\left.\mathrm{CDCl}_{3}\right) \delta$ 7.33-7.83 (m, 4H), 7.06-7.77 (m, 4H), 3.60 $(\mathrm{s}, 2 \mathrm{H}), 3.21(\mathrm{t}, 4 \mathrm{H}), 2.50(\mathrm{~s}, 3 \mathrm{H}), 2.27(\mathrm{t}, 4 \mathrm{H}), 2.26(\mathrm{~s}$, $3 \mathrm{H})$; MS: $\left[\mathrm{M}^{+}\right]: 404$, Anal. calcd. for $\mathrm{C}_{23} \mathrm{H}_{24} \mathrm{~N}_{4} \mathrm{O}_{3}$ : C, 68.16; H, 5.95; N, 13.81. Found: C, 68.30; H, 5.97; N, 13.76 .

\subsection{Preparation of 2-[4'-( $1^{\prime \prime}$-phenyl-prop-2-en-3- one)phenoxyl)-[1,4]-benzodiazepin-5-[-4" - methylpiperazinyl]-carboxamide (8)}

A mixture of 2-(4'-acetylphenoxyl)-[1,4]-benzodiazepin5-[4"-methylpiperazinyl)-carboxamide (6) (7.20 g, $0.02 \mathrm{~mol})$, benzaldehyde $(0.02 \mathrm{~mol})$, and fused sodium acetate $(0.033 \mathrm{~mol})$ in glacial acetic acid was refluxed for $5 \mathrm{~h}$. The reaction mixture was cooled and poured into water. The resulting solid was filtered, washed with water, and recrystallized from aqueous ethanol to furnish pure 8 (5.11 g, 74\%, m.p. $\left.235-236^{\circ} \mathrm{C}\right)$. IR ( $\left.\mathrm{KBr}\right)$ $\mathrm{cm}^{-1}: 2950,1680,1660,1620,1590,1550,1410,1150$, 1140; ${ }^{1} \mathrm{H}$ NMR $\left(400 \mathrm{MHz}, \mathrm{CDCl}_{3}\right) \delta \mathrm{ppm}: 7.33-7.83$ $(\mathrm{m}, 4 \mathrm{H}), 7.10-8.0(\mathrm{~m}, 4 \mathrm{H}), 6.70(\mathrm{~d}, 1 \mathrm{H}), 5.80(\mathrm{~d}, 1 \mathrm{H})$, $3.6(\mathrm{~s}, 2 \mathrm{H}), 3.20(\mathrm{t}, 4 \mathrm{H}), 2.27(\mathrm{t}, 4 \mathrm{H}), 2.25(\mathrm{~s}, 3 \mathrm{H})$; MS: $\left[\mathrm{M}^{+}\right]$: 492, Anal. Calcd. for $\mathrm{C}_{30} \mathrm{H}_{28} \mathrm{~N}_{4} \mathrm{O}_{3}: \mathrm{C}, 73.75 ; \mathrm{H}$, 5.73; N, 11.37. Found: C, 72.91; H, 5.74; N, 11.33.

\subsection{Preparation of 2-[4'-(5" - phenyldihydroisoxazol- $3^{\prime \prime}$-yl)phenoxyl]-[1,4]-benzodiazepin-5-[4"-methyl- piperazinyl-carboxamide (9)}

A solution of $(\mathbf{8})(1.14 \mathrm{~g}, 0.0025 \mathrm{~mol})$ and hydroxylamine hydrochloride $(0.15 \mathrm{~g}, 0.0025 \mathrm{~mol})$ in $20 \mathrm{~mL}$ ethanol containing $0.02 \mathrm{~g}$ of sodium hydroxide was refluxed for $12 \mathrm{~h}$, the product was isolated by concentration of the alcoholic solution, filtered, dried, and recrystallized from DMF/water to give 9 (0.583 g, 74\%, m.p. $\left.174-76^{\circ} \mathrm{C}\right)$.

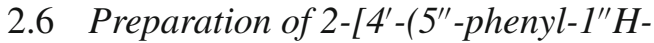
dihydropyrazol-3"-yl)phenoxyl]-[1,4]-benzodiazepin5-[4"-methyl-piperazinyl-carboxamide (10)

A mixture of $(\mathbf{8})(0.84 \mathrm{~g}, 0.001 \mathrm{~mol})$ and hydrazine hydrate $(0.20 \mathrm{~mL}, 0.002 \mathrm{~mol})$ was heated under reflux 
for $10 \mathrm{~h}$, in $25 \mathrm{~mL}$ absolute ethanol then cooled and the residual material $\mathbf{1 0}$ was filtered off and recrystallized from DMF/water $\left(0.60 \mathrm{~g}, 71 \%\right.$, m.p. $\left.210-12^{\circ} \mathrm{C}\right)$.

\subsection{Preparation of $2-\left[4^{\prime}-\left(2^{\prime \prime}-\right.\right.$ hydroxy- $6^{\prime \prime}-$} phenyldihydropyrimidin-4"-yl)phenoxyl]-[1,4]benzodiazepin-5-[4"-methyl-piperazinyl]carboxamide (11)

A mixture of (8) $(0.848 \mathrm{~g}, 0.002 \mathrm{~mol})$, urea $(0.22 \mathrm{~g}$, $0.002 \mathrm{~mol}$ ) and $0.2 \mathrm{~g} \mathrm{NaOH}$ in $25 \mathrm{~mL}$ of $80 \%$ dil. ethanol was refluxed for $7.5 \mathrm{~h}$, then concentrated and cooled, the precipitate of $\mathbf{1 1}$ was filtered off and recrystallized from DMF/water to give $(0.321 \mathrm{~g}, 75 \%$, m.p. $\left.185-86^{\circ} \mathrm{C}\right)$.

\subsection{Preparation of (2-(4-(6-phenyl-2-mercapto-5,} 6-dihydropyrimidin-4-phenoxyl)-[1,4]-benzodiazepin5-[4"-methyl-piperazinyl]-carboxamide (12)

A mixture of $(8)(0.848 \mathrm{~g}, 0.002 \mathrm{~mol})$, thiourea $(0.02 \mathrm{~g}$, $0.0030 \mathrm{~mol}$ ) and $0.2 \mathrm{~g} \mathrm{NaOH}$ in $25 \mathrm{~mL}$ of $80 \%$ dil. ethanol was refluxed for $7.5 \mathrm{~h}$, then concentrated and cooled, the precipitate of $\mathbf{1 2}$ was filtered off and recrystallized from DMF/water to give $(0.325 \mathrm{~g}, 76 \%$, m.p. $\left.210-12^{\circ} \mathrm{C}\right)$. IR $(\mathrm{KBr}) \mathrm{cm}^{-1}: 2950,1680,1660,1620$, 1590, 1550, 1410, 1150, 1140; ${ }^{1} \mathrm{H}$ NMR $(400 \mathrm{MHz}$, $\left.\mathrm{CDCl}_{3}\right) \delta$ ppm: 7.33-7.83 (m, 4H), 7.10-8.0 (m, 4H), $6.70(\mathrm{~d}, 1 \mathrm{H}), 5.80(\mathrm{~d}, 1 \mathrm{H}), 3.6(\mathrm{~s}, 2 \mathrm{H}), 3.20(\mathrm{t}, 4 \mathrm{H})$, 2.27 (t, 4H), 2.25 (s, 3H); MS: [M+ ]: 492, Anal. Calcd. for $\mathrm{C}_{30} \mathrm{H}_{28} \mathrm{~N}_{4} \mathrm{O}_{3}$ : C, 73.75; H, 5.73; N, 11.37; Found: C, $72.91 ; \mathrm{H}, 5.74 ; \mathrm{N}, 11.33$.

\subsection{General procedure for oxidation of 9-12 by} means of Iodoxybenzoic acid: General procedure for preparation of 13, 14, 15 and 16 via oxidation of 9,10 , 11 and 12

Iodoxybenzoic acid $(0.4 \mathrm{~g}, 1.53 \mathrm{mmol})$ was added as a solid to a solution of 9/10/11/12 $(0.0015 \mathrm{~mol})$ in DMSO $(1 \mathrm{~mL})$ and stirred at $45^{\circ} \mathrm{C}$ for $11 \mathrm{~h}$. The mixture was cooled to room temperature and quenched by addition of saturated aqueous $\mathrm{Na}_{2} \mathrm{~S}_{2} \mathrm{O}_{3}(1 \mathrm{~mL})$ and then basified with saturated aqueous $\mathrm{NaHCO}_{3}(1 \mathrm{~mL})$. Following extraction with EtOAc $(5 \mathrm{~mL})$, the organic phase was washed with water $(10 \mathrm{~mL})$ and brine $(10 \mathrm{~mL})$, dried $\left(\mathrm{MgSO}_{4}\right)$ and concentrated to yield the desired product.

2.9a Compound 13: Yield 64\%, m.p. $211-13^{\circ} \mathrm{C}$, IR $(\mathrm{KBr}) \mathrm{cm}^{-1}: 2950,1680,1625,550,1450,1150,1140$, 845; ${ }^{1} \mathrm{H}$ NMR (400 MHz, $\mathrm{CDCl}_{3}$ ) $\delta$ ppm: 8.10 (double $\mathrm{d}, 2 \mathrm{H}), 7.51$ (double t, 2H), $7.41(\mathrm{t}, 1 \mathrm{H}), 7.33-7.83(\mathrm{~m}$, $4 \mathrm{H}), 6.81-7.49(\mathrm{~m}, 4 \mathrm{H}), 6.3(\mathrm{~d}, 1 \mathrm{H}), 3.6(\mathrm{~s}, 2 \mathrm{H}), 3.20$ $(\mathrm{t}, 4 \mathrm{H}), 2.27(\mathrm{t}, 4 \mathrm{H}), 2.25(\mathrm{~s}, 3 \mathrm{H}) ;{ }^{13} \mathrm{C} \mathrm{NMR}(400 \mathrm{MHz}$, $\left.\mathrm{CDCl}_{3}\right) \delta$ ppm: 45, 46, 47, 49, 98, 120, 121, 125, 126, 127, 128, 129, 130, 132, 148, 155, 162, 164, 169; MS: $\left[\mathrm{M}^{+}\right]$: 505, Anal. calcd. for $\mathrm{C}_{30} \mathrm{H}_{27} \mathrm{~N}_{5} \mathrm{O}_{3}$ : C, 71.27; $\mathrm{H}$, 5.38; N, 13.85; Found: C, 71.37; H, 5.36; N, 13.92.

2.9b Compound 14: Yield 65\%, m.p. $220-21^{\circ} \mathrm{C}$. IR $(\mathrm{KBr}) \mathrm{cm}^{-1}: 3440,2945,1690,1620,1590,1525,1465$, 1135, 1030; ${ }^{1} \mathrm{H}$ NMR (400 MHz, $\left.\mathrm{CDCl}_{3}\right) \delta$ ppm: 13.7 (s, 1H), 8.05 (double d, 2H), 7.51 (double t, 2H), 7.41 (t, 1H), 7.33-7.83 (m, 4H), $6.81(\mathrm{~d}, 1 \mathrm{H}), 6.81-7.49(\mathrm{~m}$, $4 \mathrm{H}), 3.6(\mathrm{~s}, 2 \mathrm{H}), 3.21(\mathrm{t}, 4 \mathrm{H}), 2.27(\mathrm{t}, 4 \mathrm{H}), 2.23(\mathrm{~s}, 3 \mathrm{H})$; ${ }^{13} \mathrm{C}$ NMR $\left(400 \mathrm{MHz}, \mathrm{CDCl}_{3}\right) \delta$ ppm: 45, 47, 49, 99, $116,125,127,128,129,130,132,133,147,148,155$, 158, 164; MS: $\left[\mathrm{M}^{+}\right]$: 504, Anal. calcd. for $\mathrm{C}_{30} \mathrm{H}_{28} \mathrm{~N}_{6} \mathrm{O}_{2}$ : C, 71.41; H, 5.59; N, 16.66; Found: C, 71.52; H, 5.56; $\mathrm{N}, 16.61$.

2.9c Compound 15: Yield 60\%, m.p. $240-42^{\circ} \mathrm{C}$. IR $(\mathrm{KBr}) \mathrm{cm}^{-1}$ : 3490, 2990, 1685, 1625, 1545, 1425, 1165, 1060; ${ }^{1} \mathrm{H}$ NMR $\left(400 \mathrm{MHz}, \mathrm{CDCl}_{3}\right) \delta \mathrm{ppm}: 11.34$ (s, 1H), 7.79 (double d, 2H), 7.51 (double t, 2H), 7.41 (t, $1 \mathrm{H}), 7.63(\mathrm{~s}, 1 \mathrm{H}), 7.33-7.83(\mathrm{~m}, 4 \mathrm{H}), 6.81-7.49(\mathrm{~m}$, $4 \mathrm{H}), 3.6(\mathrm{~s}, 2 \mathrm{H}), 3.21(\mathrm{t}, 4 \mathrm{H}), 2.27(\mathrm{t}, 4 \mathrm{H}), 2.23(\mathrm{~s}$, $3 \mathrm{H}) ;{ }^{13} \mathrm{C}$ NMR $\left(400 \mathrm{MHz}, \mathrm{CDCl}_{3}\right) \delta$ ppm: 45, 47, 49, 95, 116, 126, 127, 128, 129, 130, 132, 135, 148, 154, 155, 158, 160, 162, 164; MS: [M $\left.{ }^{+}\right]$: 532, Anal. calcd. for $\mathrm{C}_{31} \mathrm{H}_{28} \mathrm{~N}_{6} \mathrm{O}_{3}: \mathrm{C}, 69.91 ; \mathrm{H}, 5.30 ; \mathrm{N}, 15.78$; Found: $\mathrm{C}$, 69.75; H, 5.29; N, 15.75 .

2.9d Compound 16: Yield 61\%, m.p. 230-32 ${ }^{\circ}$ C. IR $(\mathrm{KBr}) \mathrm{cm}^{-1}:$ 2960, 2250, 1680, 1660, 1570, 1420, 1155, 1060; ${ }^{1} \mathrm{H}$ NMR $\left(400 \mathrm{MHz}, \mathrm{CDCl}_{3}\right) \delta$ ppm: 12.15 (s, $1 \mathrm{H}), 8.41(\mathrm{~s}, 1 \mathrm{H}), 7.79$ (double d, 2H), 7.51 (double $\mathrm{t}, 2 \mathrm{H}), 7.41(\mathrm{t}, 1 \mathrm{H}), 7.33-7.83(\mathrm{~m}, 4 \mathrm{H}), 6.81-7.49(\mathrm{~m}$, $4 \mathrm{H}), 3.6(\mathrm{~s}, 2 \mathrm{H}), 3.20(\mathrm{t}, 4 \mathrm{H}), 2.27(\mathrm{t}, 4 \mathrm{H}), 2.26(\mathrm{~s}$, $3 \mathrm{H}) ;{ }^{13} \mathrm{C}$ NMR $\left(400 \mathrm{MHz}, \mathrm{CDCl}_{3}\right) \delta$ ppm: $38,45,49$, 57, 109, 116, 122, 127, 128, 129, 130, 132, 149, 157,

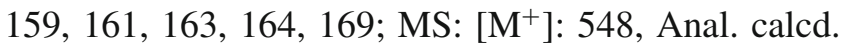
for $\mathrm{C}_{31} \mathrm{H}_{28} \mathrm{~N}_{6} \mathrm{O}_{2} \mathrm{~S}: \mathrm{C}, 67.86 ; \mathrm{H}, 5.14 ; \mathrm{N}, 15.32 ; \mathrm{S}, 5.84$; Found: C, 67.66; H, 5.13; N, 15.35, S, 5.82.

\section{Biological studies}

All the compounds were screened for their antimicrobial activity by disc diffusion method at $100 \mu \mathrm{g} / \mathrm{mL}$ concentration in DMF against Pseudomonas aeruginosa (MTCC 1688) and Bacillus cerus (MTCC 1305) 
Table 1. Antibacterial and antifungal activity of compounds 13-16.

\begin{tabular}{|c|c|c|c|c|c|c|c|c|}
\hline \multirow[b]{2}{*}{$\begin{array}{l}\text { Comp. } \\
\text { No. }\end{array}$} & \multicolumn{2}{|c|}{ Pseudomonas aeruginosa } & \multicolumn{2}{|c|}{ Bacillus cerus } & \multicolumn{2}{|c|}{ Macrophomina phaseolina } & \multicolumn{2}{|c|}{ Fusarium solani } \\
\hline & $\begin{array}{c}\text { Zone of } \\
\text { inhibition }\end{array}$ & $\begin{array}{l}\% \text { activity } \\
\text { compared to } \\
\text { the standard }\end{array}$ & $\begin{array}{l}\text { Zone of } \\
\text { inhibition }\end{array}$ & $\begin{array}{l}\% \text { activity } \\
\text { compared to } \\
\text { the standard }\end{array}$ & $\begin{array}{c}\text { Zone of } \\
\text { inhibition }\end{array}$ & $\begin{array}{l}\% \text { activity } \\
\text { compared to } \\
\text { the standard }\end{array}$ & $\begin{array}{l}\text { Zone of } \\
\text { inhibition }\end{array}$ & $\begin{array}{l}\% \text { activity } \\
\text { compared to } \\
\text { the standard }\end{array}$ \\
\hline 13 & 18 & 90.0 & 11 & 61.1 & 21 & 95.4 & 12.5 & 56.8 \\
\hline 14 & 11 & 55.0 & 14 & 77.7 & 19.9 & 90.4 & 11.4 & 51.8 \\
\hline 15 & 12 & 60.0 & 11 & 61.1 & 17 & 77.2 & 12.3 & 55.9 \\
\hline 16 & 12.5 & 62.5 & 16 & 88.8 & 21 & 95.4 & 15.4 & 70.0 \\
\hline
\end{tabular}

and antifungal activity against Macrophomina phaseolina (MTCC 166) and Fusarium solani (MTCC 350). The zone of inhibition and activity index were determined in comparison of the standard drugs 'streptomyacin' and 'fluconazol'. The outcome of this study is presented in table 1 . All these compounds were active against the bacterial and fungal strains.

\section{Results and discussion}

Development of methodologies to facilitate the preparation of compound libraries based on the privileged structures is an intense area of research in organic and medicinal chemistry. In this paper, we report the preliminary results of our study focused in the direction of the development of compound libraries from the privileged 1,4-benzodiazepine nucleus. ${ }^{11,12}$ The synthetic plan depicted in schemes 1 and 2 for the preparation of 9-16 proceeded with the easily accessible 5-carbomethoxy substituted 1,4-benzodiazepin-2-one (3), which was realized through reported procedure ${ }^{13,14}$ which consisted of the reaction of methanolic solution of hexamine on $N$-chloroacetylisatin (2). The carbomethoxy function of $\mathbf{3}$ on treatment with $\mathrm{N}$-methylpiperazine formed the corresponding $\mathrm{C}_{5}$-carboxamido derivative (4). ${ }^{15}$ This on treatment with $\mathrm{POCl}_{3}$ in the presence of the base (dimethylaniline) yielded the corresponding 2-chloro derivative (5) whose subsequent reaction with $p$-hydroxyacetophenone afforded the corresponding 2-(4'-acetylphenoxyl) substituted derivative (6). ${ }^{16}$ It was reacted with benzaldehyde (7) to obtain the chalcone derivative (8). The compound $\mathbf{8}$ underwent a

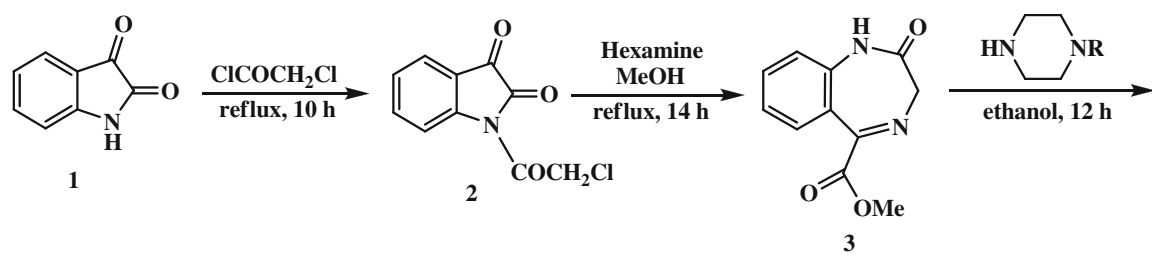

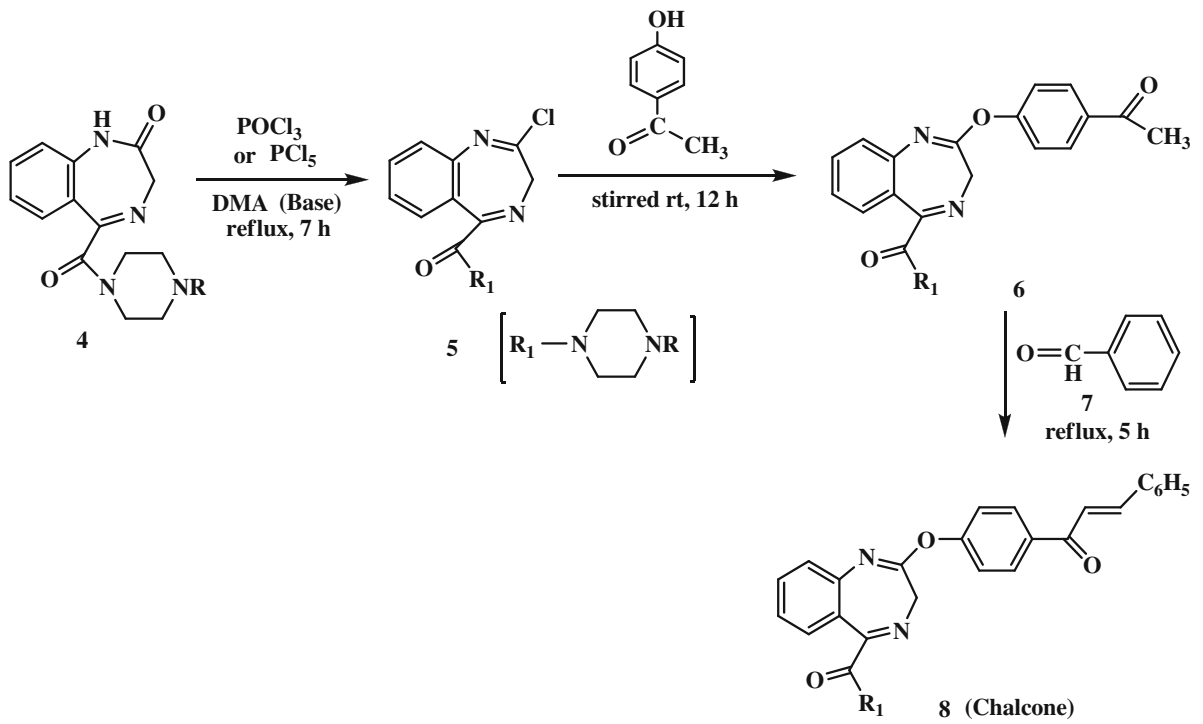

Scheme 1. Synthesis of Chalcones. 


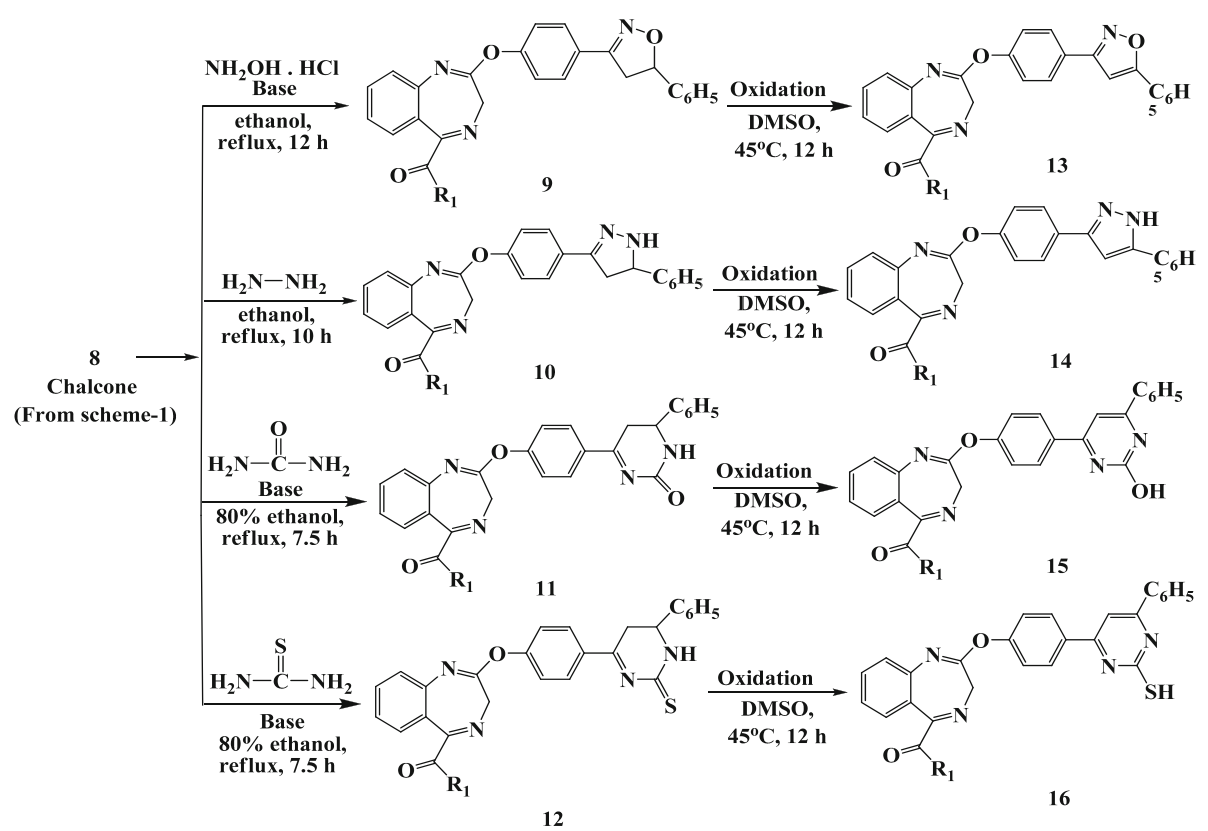

Scheme 2. Synthesis of isoxazole, pyrazole and pyrimdine derivatives of 1,4-benzodiazepine.

facile cyclocondensation reaction with hydroxylamine hydrochloride and hydrazine hydrate to form the isoxazole and pyrazole derivatives $\mathbf{9}$ and $\mathbf{1 0}$, respectively. In another reaction the versatility of $\mathbf{8}$ was exploited with urea and thiourea to afford the pyrimidine derivatives (11-12) in good yield. Compounds 9-13 are dihydro compounds, oxidation of which with iodoxybenzoic acid ${ }^{17}$ afforded 13, 14, 15 and 16 in acceptable yields and purity (scheme 2). The microanalysis, IR, ${ }^{1} \mathrm{H}$ NMR, ${ }^{13} \mathrm{C}$ NMR, and MS spectral data were found to be consistent to the structures assigned to these molecules. The spectra of these compounds unequivocally established the structures of these materials. The most diagnostic evidence for their formation was provided by the appearance of a signal at $\delta 13.7$ in ${ }^{1} \mathrm{H}$ NMR spectrum of the pyrazole $\mathrm{NH}$ in $\mathbf{1 4}$, at $\delta 11.34$ for the $\mathrm{OH}$ in $\mathbf{1 5}$, at $\delta 12.15$ for the SH group in $\mathbf{1 6}$. The appearance of the $\mathrm{M}+$ peaks corresponding to their molecular weight in MS spectrum confirmed their formation and established their structures, which were confirmed further by the data available from ${ }^{13} \mathrm{C}$ NMR spectrum.

\section{Conclusion}

In summary, two noteworthy features on the synthesis have been evident from our study. The cytotoxic properties of pyrrolo-[2,1-c][1,4]-benzodiazepine class of antibiotics have been implicated due to the intercalation of DNA with the $\mathrm{C}_{11}$ function of these molecules. In this context, the synthesis of $\mathrm{C}_{2}$-substituted $\left(\mathrm{C}_{11}\right.$ in the case of pyrrolo-[2,1-c][1,4]-benzodiazepine) was of immense significance. In this context, the proposed strategy on the one hand, has sought to provide a convenient one-step synthetic entry to the heterocycles such as pyrazole, isoxazole, and pyrimidine rings on the $\mathrm{C}_{2}$ of 1,4-benzodiazepine nucleus from the corresponding chalcone derivatives and on the other hand, has provided a clean and practical route to the incorporation of the bioactive pharmacophores of medicinal utility, on to the $\mathrm{C}_{2}$ of this privileged nucleus.

\section{Acknowledgements}

Authors are thankful to Punjab University, Chandigarh for providing the spectral data of the compounds. Authors are also thankful to the Department of Science and Technology (DST), New Delhi for financial support provided to Banasthali University for research programme.

\section{References}

1. Bariwal J B, Upadhyay K D, Manvar A T, Trivedi J C, Singh J S, Jain K S and Shah A K 2008 Eur. J. Med. Chem. 432279

2. Araujo A C, Rauter A P, Nicotra F, Airoldi C, Costa B and Cipolla L 2011 J. Med. Chem. 541266

3. Piao F Y, Han R B, Zhang W, Zhang W B and Jiang R S 2011 Eur. J. Med. Chem. 461050

4. Cipolla L, Araujo A C, Airoldi C and Bini D 2009 AntiCanc. Agents Med. Chem. 91

5. Anzini M, Valenti S, Braile C, Cappelli A, Vomero S and Stefano 2011 J. Med. Chem. 545694 
6. De T P, Delarge J and Pirotte B 2000 Exp. Opin. Invert Drugs 9129

7. Wainberg M A 2003 J. Асqu. Iтmи. Defi. Syndr. 342

8. Lansdon E B, Brendza K M, Hung M, Wang R, Mukund S, Jin D, Birkus G, Kutty N and Liu X $2010 \mathrm{~J}$. Med. Chem. $\mathbf{5 3} 4295$

9. Manvar A, Bochiya P, Virsodia V, Khunt R and Shah A 2007 J. Mol. Catal. A Chem. 275148

10. Khunt R C, Akbari J D, Manvar A T, Tala S D, Dhaduk M F, Joshi H S and Shah A 2008 Arkivoc (xi), 277

11. Antonow D and Thurston D E 2011 Chem. Rev. 111 2815
12. Akgun E, Korner M, Gao F, Harkumar K G, Waser B, Reubi J C, Portoghese P S and Miller L J 2009 J. Med. Chem. $\mathbf{5 2} 2138$

13. Ogata M and Matsumoto H 1976 Chem. Ind. (London) 1067

14. Sharma P, Vashistha B, Tyagi R, Srivastava V, Shorey M, Singh B and Kishore D 2010 Int. J. Chem. Sci. 841

15. Nicolaou K C, Mathison C J N and Montagnon T 2004 J. Am. Chem. Soc. 1265192

16. Pathak V N, Joshi R and Gupta N 2007 Indian J. Chem. 46B 1191

17. Nicolaou K C, Mathison C J N and Montagnon T 2004 J. Am. Chem. Soc. 1265192 